\title{
PENGARUH PERSEPSI EKOWISATA TERHADAP TINGKAT KEPUASAN WISATAWAN DI MONKEY FOREST UBUD, BALI
}

\author{
Via Reza Efrida \\ I Nyoman Sudiarta \\ Ni Putu Eka Mahadewi \\ Email: viarezaefrida@gmail.com \\ PS. S1 Industri Perjalanan Wisata \\ Fakultas Pariwisata UNUD
}

\begin{abstract}
This study aims to investigate (1) the ecotourism perception of tourists visiting Monkey Forest Ubud; (2) the visitor satisfaction level on Monkey Forest Ubud attraction; and (3) the influence of ecotourism perception on visitor satisfaction level at Monkey Forest Ubud. The result of this research carried out descriptive statistic by using an importance-performance analysis (IPA) and inferential statistic by using a simple linear regression analysis. The technique of determining sample size is incidental sampling technique by distributing questionnaires to 170 tourists visiting Monkey Forest Ubud. The result showed that tourists which visit Monkey Forest Ubud strongly agree on the implementation of ecotourism concept. On the other hand, the calculation results of concordance rate showed $89.59 \%$ which means that the overall tourist is satisfied with the Monkey Forest Ubud attraction. Moreover, based on the hypothesis testing by using t-test statistical significance showed that there is a significant influence of independent variable (perception of ecotourism) on the dependent variable (tourist satisfaction).
\end{abstract}

Keywords : Perception of Ecotourism, Tourist Satisfaction.

\section{PENDAHULUAN}

Pariwisata dewasa ini mendapat perhatian serius para akademisi maupun praktisi (UNWTO, Wang 2015, Sudiarta dan Suardana 2016). Sebab tak dapat dipungkiri bahwa pariwisata ditengah ketenarannya yang mampu memberikan konstribusi positif terhadap peningkatan sektor ekonomi, nyatanya juga tidak terlepas dari dampak negatif. Salah satunya ialah mengenai dampak negatif pariwisata terhadap lingkungan dan sosial. Tak heran jika tren baru dalam pariwisata muncul seiring dengan kemajuannya yang tidak dapat terbendung. Buku yang dipublikasikan oleh The World Tourism Organization atau yang lebih dikenal dengan istilah UNWTO (1998: 19-20) memaparkan bahwa salah satu tren utama dalam pariwisata merujuk pada customer behaviour change atau perubahan perilaku wisatawan. Tren tersebut berupa fakta bahwa banyak wisatawan kini menjadi sensitif terhadap isu lingkungan dan sosial serta mencari hal-hal yang didesain baik guna mengurangi polusi pada destinasi pariwisata.

Melalui tren customer behaviour change tersebut, lahirlah bentuk pariwisata alternatif sebagai bentuk jawaban atas tantangan permintaan pasar yang berkembang ke arah sustainability. Salah satu bentuk pariwisata alternatif tersebut dikenal dengan istilah ecotourism atau ekowisata. UNWTO (1999: 120) mendefinisikan ekowisata sebagai bentuk realisasi pariwisata berkelanjutan dengan memerhatikan 'kaidah' alam. Akan tetapi, muncul satu isu yang dihadapi oleh para pelaku bisnis pariwisata ialah adanya pemahaman bahwa ekowisata dibayangi oleh aturan daya dukung atau "carrying capacity". Aturan tentang carrying capacity ini akan menimbulkan konflik pada kubu pengelola dan pelaku bisnis pariwisata mengingat 
keuntungan yang diperoleh tersebut berasal dari wisatawan.

Merujuk pada pemaparan Sullivan dkk (1995) mengenai pola hubungan pariwisata dengan ekologi yang berujung pada keberlanjutan ekonomi mengindikasikan bahwa customer satisfaction merupakan salah satu aspek penting dalam mempertemukan nilai ekologi pada profitabilitas. Tak hanya itu saja, fakta lain juga mengungkapkan jika kemampuan ekonomi (willingness to pay) ekowisatawan relatif di atas rata-rata wisatawan pada umumnya (Damanik dan Weber, 2006: 47). Karena itulah, penting dalam praktek pelaksanaan ekowisata guna memerhatikan tingkat kepuasan wisatawan sebagai bentuk apresiasi terhadap "willingness to pay" mereka yang melebihi wisatawan konvensional pada umumnya tersebut.

Adapun konsep kepuasan pelanggan yang dikemukakan oleh Irawan (2008: 37-39) menyatakan bahwa salah satu faktor pendorong kepuasan pelanggan ialah emotional factor. Emotional factor yang dimaksud disini ialah pelanggan akan merasa puas (bangga) karena adanya emosional value yang diberikan oleh brand dari suatu produk. Penjabaran konsep kepuasan pelanggan yang dipaparkan oleh Irawan (2008) tersebut menyiratkan fakta bahwa salah satu faktor yang mendorong kepuasan wisatawan terhadap ekowisata adalah emotional value. Hal ini didasari oleh adanya persepsi wisatawan terhadap ekowisata yang mampu menghasilkan emotional value yakni rasa bangga atas mengkonsumsi produk ekowisata.

Nilai dari rasa bangga tersebut diperoleh wisatawan atas dasar keyakinan bahwa ekowisata dianggap sebagai bentuk pariwisata yang pro terhadap lingkungan, meningkatkan perekonomian daerah serta mampu menjadi ruang keterlibatan masyarakat lokal terhadap pengelolaan suatu destinasi pariwisata secara langsung, sekaligus mempertahankan nilai-nilai budaya luhur yang mereka anut. Sehingga dengan kata lain, kunjungan para wisatawan ke suatu destinasi ekowisata membantu pencapaian tersebut dan mereka bangga karena mampu menjadi bagian penting dalam realisasi tujuan-tujuan mulia tersebut.

Maka dalam analisis tingkat kepuasan wisatawan sebagai bentuk evaluasi terhadap praktek realisasi konsep ekowisata, penting untuk mengetahui terlebih dahulu tentang bagaimana persepsi wisatawan terhadap ekowisata serta pengaruhnya terhadap kepuasan wisatawan tersebut. Pemilihan lokasi didasari atas informasi dalam buku yang ditulis oleh Arida (2016: 86). Informasi tersebut menyebutkan bahwa salah satu jenis objek ekowisata yang telah tumbuh di Bali adalah Monkey Forest Ubud. Konsep pengelolaan Monkey Forest Ubud dapat dikatakan sebagai cerminan sebuah ekowisata yang kompleks. Sebab eksistensi Ekowisata Monkey Forest Ubud dinaungi oleh tujuan pelestarian lingkungan alam dan habitat margasatwa (utamanya kera Bali ekor panjang), penggerak ekonomi masyarakat lokal serta perwujudan nilai-nilai budaya melalui implementasi filosofi Tri Hita Karana.

Terkait penilaian wisatawan terhadap destinasi pariwisata Monkey Forest Ubud sejauh ini dapat diketahui melalui informasi dari laman resmi TripAdvisor. Pada laman tersebut mengungkapkan informasi mengenai penilaian wisatawan yang datang berkunjung ke Monkey Forest Ubud. Data paling update pada laman TripAdvisor tersebut kini telah menyentuh angka total 17.421 ulasan (reviews). Dari total 17.421 ulasan tersebut menunjukkan bahwa ternyata mayoritas wisatawan yang berkunjung ke Monkey Forest Ubud memberikan nilai positif. Artinya bahwa dari keseluruhan ulasan tersebut, mayoritas wisatawan (81\%) yang berkunjung ke Monkey Forest Ubud merasa puas. Namun harus ditekankan bahwa beberapa penilaian buruk wisatawan terhadap destinasi pariwisata Monkey Forest Ubud tersebut tetap tidak dapat disepelekan.

Oleh karena itu, perlu adanya evaluasi mengenai sudut pandang wisatawan terhadap pelaksanaan konsep ekowisata, sekaligus mengetahui tingkat kepuasan mereka di Monkey Forest Ubud. Di sisi lain, guna mengetahui bagaimana hubungan antara kedua variabel tersebut, maka evaluasi mengenai pengaruh persepsi ekowisata terhadap tingkat kepuasan wisatawan di Monkey Forest Ubud juga perlu dilaksanakan.

\section{METODE}

Terdapat lima dimensi dari variabel bebas persepsi ekowisata yaitu: (1) resources and content, (2) giving back to the community, (3) environmental education and interpretation, (4) public-private partnership, serta (5) concept of sustainable tourism. 
Sedangkan pada variabel terikat kepuasan wisatawan terdapat lima dimensi yaitu: (1) service of staff, (2) tangibles, environmental education, interpretation, and communication, (4) sanitation and hygiene, serta (5) natural resources and content.

Teknik pengumpulan data yang digunakan ialah observasi, wawancara, kuesioner, dan studi kepustakaan. Penentuan sampel dilakukan dengan teknik sampling incidental yaitu siapa saja yang secara kebetulan/insidental dapat digunakan sebagai sampel, bila dipandang orang yang kebetulan ditemui itu cocok sebagai sumber data (Sugiyono 2014: 85). Adapun jumlah responden yang digunakan ialah sebanyak 170 orang dengan pertimbangan usia minimal 16 tahun. Teknik analisis data menggunakan pendekatan mix method yakni analisis kualitatif dan analisis kuantitatif. Teknik analisis statistik deskriptif yang digunakan ialah Importance-Performance Analysis (IPA) sedangkan untuk analisis statistik inferensial yang digunakan ialah analisis regresi linear sederhana.

\section{HASIL}

\section{Karakteristik Wisatawan}

Karakteristik responden berdasarkan asal negaranya menunjukkan bahwa dari 170 responden yang mengisi kuesioner merupakan wisatawan yang berasal dari 32 negara yang berbeda-berbeda dengan nilai persentase terbesar diperoleh oleh wisatawan yang berasal dari UK yakni sebesar 11,18\%. Berdasarkan jenis kelamin, jumlah terbanyak berasal dari wisatawan wanita dengan persentase sebesar 55,29\%. Pada karakteristik wisatawan berdasarkan usia dan tingkat pendidikan, jumlah terbanyak ialah wisatawan dengan rentang usia 26-30 tahun sebesar $38,24 \%$ serta lulusan Sarjana (Bachelor) dan/atau Diploma 4 sebesar 48,82\%.

Wisatawan paling banyak merupakan first timer $(89,41 \%)$ dan melaksanakan perjalanan wisatanya tanpa bantuan jasa travel agent (85,88\%). Selain itu, mereka berkunjung ke Monkey Forest Ubud paling banyak bersama teman $(52,94 \%)$ dengan jumlah anggota grup sebanyak 2-3 orang (72,94\%). Mayoritas dari para wisatawan tersebut $(42,94 \%)$ tinggal di Bali selama rentang waktu 8-14 hari. Motivasi utama mereka berkunjung ke Monkey Forest Ubud (60\%) ialah untuk melihat keindahan alam. Terakhir, karakteristik wisatawan berdasarkan willingness to pay menunjukkan bahwa jawaban terbanyak berasal dari kategori setuju dengan persentase sebesar 40,59\%. Hal ini menunjukkan bahwa sebanyak 69 orang merasa setuju jika harus membayar lebih untuk kegiatan-kegiatan wisata berbasis alam.

\section{Hasil Analisis Data}

Berdasarkan hasil analisis deskriptif variabel persepsi ekowisata secara keseluruhan yang dihitung berdasarkan jumlah nilai ratarata dari seluruh atribut ialah sebesar 4,35 yang mengindikasikan sangat setuju. Hal ini menunjukkan bahwa secara keseluruhan, wisatawan sangat setuju terhadap konsep fungsi dan implementasi ekowisata. Sehingga dapat disimpulkan bahwa wisatawan yang berkunjung ke Monkey Forest Ubud memiliki persepsi yang positif terhadap praktek pelaksanaan dan pengembangan ekowisata.

Di sisi lain, hasil penghitungan dengan rumus tingkat kepuasan diperoleh nilai sebesar $89,59 \%$. Nilai tersebut memiliki arti bahwa dari 170 wisatawan yang diminta untuk mengisi kuesioner, secara keseluruhan wisatawan tersebut merasa puas terhadap halhal yang ditawarkan oleh daya tarik wisata Monkey Forest Ubud berdasarkan seluruh atribut penilaian yang digunakan. Adapun faktor-faktor pada indikator-indikator kepuasan wisatawan yang dianggap penting bagi wisatawan namun tidak memuaskan dalam pelaksanaannya merupakan faktor utama yang harus ditingkatkan. Faktor-faktor tersebut meliputi kebersihan toilet, kebersihan seluruh area Monkey Forest Ubud termasuk area parkir, penempatan beberapa tempat sampah di area Monkey Forest Ubud serta kecakapan staf dalam memberikan informasi guna menjawab permintaan pengunjung.

Selain itu, terdapat faktor-faktor yang dianggap penting oleh wisatawan dan pelaksanaannya dinilai sangat memuaskan. Faktor-faktor tersebut harus selalu dipertahankan agar kepuasan wisatawan juga dapat dipertahankan meliputi area lingkungan destinasi pariwisata Monkey Forest Ubud yang menarik, ketersediaan papan-papan pemberi tanda arah yang tersedia di Monkey Forest Ubud guna menunjukkan area sekitar secara jelas kepada pengunjung/wisatawan, fasilitas fisik yang terpelihara dengan baik, ketersediaan informasi mengenai tindakantindakan yang dibatasi maupun yang tidak 
diperbolehkan (dilarang) di area Monkey Forest Ubud serta keunikan dan keotentikan daya tarik Monkey Forest Ubud di mata para wisatawannya.

Berdasarkan hasil uji validitas variabel persepsi ekowisata serta variabel kepuasan wisatawan menunjukkan bahwa masingmasing instrumen memiliki nilai r-hitung lebih besar dari nilai r-tabel (r-hitung $>$ r-tabel). Hasil uji validitas ini mengindikasikan bahwa seluruh instrumen yang digunakan ialah valid. Sedangkan pada hasil uji reliabilitas menghasilkan nilai cronbach's alpha sebesar 0,879 . Nilai cronbach's alpha tersebut lebih besar dari 0,6 yang artinya bahwa koefisien reliabilitas $\left(r_{11}\right)=0,879>0,6$ sehingga instrumen dinyatakan reliabel.

Uji asumsi klasik terdiri dari dua pengujian yakni uji normalitas serta uji heteroskedastisitas. Hasil uji normalitas Kolmogorov Smirnov diperoleh nilai signifikansi sebesar 0,846 yang berarti nilai tersebut lebih besar dari 0,05 $(0,846>0,05)$. Hasil uji normalitas tersebut menyimpulkan bahwa data berdistribusi normal. Sedangkan hasil uji heteroskedastisitas menghasilkan nilai signifikansi sebesar 0,079 yang berarti lebih besar dari $0,05(0,079>0,05)$ maka artinya tidak terjadi heteroskedastisitas.

Pada hasil uji korelasi diperoleh nilai korelasi sebesar 0,433. Nilai $\mathrm{R}=0,433$ memiliki nilai positif $(+)$ artinya bahwa terjadi hubungan searah antara variabel persepsi ekowisata dan variabel kepuasan wisatawan di Monkey Forest Ubud. Hal ini mengindikasikan bahwa apabila nilai variabel persepsi ekowisata naik, maka variabel kepuasan wisatawan juga akan naik. Sedangkan dari sisi kuat lemahnya hubungan antara variabel $\mathrm{X}$ dengan variabel $\mathrm{Y}$, diperoleh nilai sebesar 0,433 yang berarti bahwa variabel persepsi ekowisata memiliki hubungan yang cukup kuat dengan variabel kepuasan wisatawan.

Berdasarkan hasil penghitungan analisis koefisien determinasi menunjukkan bahwa $18,8 \%$ kepuasan wisatawan yang datang berkunjung ke Monkey Forest Ubud ditentukan atau dipengaruhi oleh adanya persepsi ekowisata yang mereka miliki. Di sisi lain, hasil uji analisis regresi linear sederhana menunjukkan nilai koefisien persepsi ekowisata (X) sebesar 0,449 dan bernilai positif. Nilai positif pada koefisien variabel independen menunjukkan hubungan yang searah. Artinya bahwa ketika persepsi ekowisata meningkat sebesar 1 (satu) satuan, maka kepuasan wisatawan yang berkunjung ke Monkey Forest Ubud (Y) juga akan meningkat sebesar 0,449 .

Adapun hasil uji hipotesis menghasilkan nilai t-hitung sebesar 6,228 dan jika dibandingkan dengan nilai t-tabel $=1,974$ maka didapat kesimpulan bahwa t-hitung $>\mathrm{t}-$ tabel $(6,228>1,974)$. Sedangkan untuk nilai signifikansinya sebesar 0,000 yang berarti lebih kecil dari nilai probabilitas $0,05(0,000<$ 0,05). Sehingga dapat disimpulkan bahwa variabel bebas persepsi ekowisata berpengaruh secara signifikan terhadap variabel terikat kepuasan wisatawan di Monkey Forest Ubud Bali.

\section{PEMBAHASAN}

Persepsi Ekowisata dari Sudut Pandang Wisatawan yang Berkunjung ke Monkey Forest Ubud

Hasil analisis deskriptif variabel persepsi ekowisata menyatakan bahwa secara keseluruhan, wisatawan sangat setuju terhadap implementasi konsep ekowisata. Persepsi wisatawan yang positif ini merupakan kabar baik bagi pihak Monkey Forest Ubud. Sebab, selama ini pihak Monkey Forest Ubud telah banyak mengupayakan program-program yang selaras dengan konsep ekowisata. Realisasi konsep ekowisata yang paling mencolok dalam manajemen pengelolaan Monkey Forest Ubud ialah upaya pelestarian lingkungan. Adapun upaya pelestarian lingkungan yang dilakukan oleh pihak manajemen Monkey Forest Ubud selama ini meliputi perluasan kawasan hutan, penanaman pohon dan penataan taman, pengontrolan asupan makanan kera dan populasi kera, perawatan bagi kera yang sakit, serta penerapan peraturan dengan diberlakukannya kawasan Monkey Forest Ubud sebagai kawasan bebas asap rokok dan bebas dari sampah plastik.

Di sisi lain, menyikapi salah satu indikator pada variabel persepsi ekowisata yakni "ecotourism should aim at groups with small numbers of tourists" menunjukkan nilai pada kategori "setuju". Artinya wisatawan setuju bahwa ekowisata dalam pelaksanaannya seharusnya mengarah pada wisatawan dengan jumlah kelompok yang kecil. Berdasarkan hasil wawancara dengan Bapak I Nyoman Buana selaku General Manager pada manajemen Mandala Suci Wenara Wana 
(Monkey Forest Ubud), menyatakan bahwa pihak manajemen Monkey Forest Ubud telah lama memikirkan tentang carrying capacity atau daya dukung. Namun sampai saat ini belum menemukan titik terang tentang bagaimana cara membatasi jumlah kunjungan wisatawan tersebut. Dikunjungi oleh sekitar seribu orang setiap harinya, pihak manajemen Monkey Forest Ubud menyadari bahwa jumlah tersebut tergolong tidak sedikit dan jika tidak ada perbincangan serius mengenai carrying capacity, maka dikhawatirkan akan memberikan dampak buruk di kemudian hari.

\section{Tingkat Kepuasan Wisatawan Terhadap Daya Tarik Wisata Monkey Forest Ubud}

Hasil penghitungan pada nilai tingkat kesesuaian diperoleh nilai sebesar 89,59\% yang mengindikasikan bahwa secara keseluruhan, wisatawan merasa puas terhadap daya tarik wisata Monkey Forest Ubud. Selain itu, berdasarkan analisis kuadran dengan menggunakan diagram kartesius menunjukkan bahwa faktor utama yang harus dibenahi guna meningkatkan kepuasan wisatawan adalah kebersihan toilet. Sebab nilai tingkat kesesuaian pada faktor kebersihan toilet yang hanya sebesar $70 \%$ ini sangat kecil dibandingkan dengan faktor-faktor lainnya. Sehingga pihak pengelola Monkey Forest Ubud dirasa sangat perlu untuk meningkatkan kebersihan toilet-toilet yang tersedia pada kawasannya tersebut. Berdasarkan hasil observasi yang dilakukan, pihak Monkey Forest Ubud telah menyediakan sejumlah toilet yang tersebar pada zona-zona yang strategis. Perlengkapan toilet yang disediakan juga telah memadai misalnya terdapat wastafel, penyediaan tissue, hand dryer, dan sebagainya.

Namun banyak wisatawan yang menilai kebersihan toilet-toilet yang tersedia di kawasan Monkey Forest Ubud masih kurang terjaga. Sebab lantai toilet sering dalam keadaan basah dan karena sering keluar masuknya wisatawan menyebabkan lantai yang basah tersebut menjadi kotor. Perlu penanganan yang lebih maksimal guna menjaga kebersihan toilet-toilet tersebut agar sesuai dengan ekspektasi para pengunjung. Sehingga disarankan agar pihak pengelola Monkey Forest Ubud menugaskan staf secara lebih intensif di seluruh area toilet yang mereka miliki.
Sedangkan faktor kedua yang mendapatkan prioritas utama ialah faktor penempatan beberapa tempat sampah di area Monkey Forest Ubud sebesar 80.34\%. Hal ini mengindikasikan bahwa penempatan beberapa tempat sampah di area Monkey Forest Ubud belum diletakkan di tempat-tempat yang tepat untuk digunakan. Sebenarnya beberapa tempat sampah telah banyak diletakkan pada beberapa zona, namun penempatan tersebut belum diaplikasikan ke zona-zona yang strategis mengingat masih banyak wisatawan yang kebingungan dalam mencari tempat sampah di kawasan tersebut.

Adapun faktor ketiga yang perlu mendapatkan prioritas utama ialah faktor kebersihan seluruh area Monkey Forest Ubud (termasuk area parkir) yang hanya memiliki nilai tingkat kesesuaian sebesar 84,04\%. Kebersihan seluruh area Monkey Forest Ubud ini dinilai kurang sebab terdapat banyak sekali daun-daun serta kulit pisang yang berserakan di hampir seluruh area Monkey Forest Ubud. Namun beberapa wisatawan juga masih memaklumi hal tersebut mengingat kawasan Monkey Forest Ubud sebenarnya merupakan kawasan hutan yang dirubah menjadi kawasan wisata dengan menganut konsep konservasi alam. Selain itu, beberapa kulit pisang yang berserakan merupakan sampah yang berasal dari makanan kera yang menghuni kawasan tersebut. Di sisi lain, banyaknya wisatawan yang gemar memberi pisang untuk para kera merupakan pemandangan yang umum di kawasan Monkey Forest Ubud ini. Sehingga untuk mengantisipasi banyaknya sampah kulit pisang yang berserakan di area Monkey Forest Ubud tersebut, maka salah satu cara yang dapat diterapkan ialah memberikan pisang yang kulitnya telah dikupas sebagai makanan kera.

\section{Analisis Pengaruh Persepsi Ekowisata Terhadap Tingkat Kepuasan Wisatawan di Monkey Forest Ubud}

Hasil uji hipotesis melalui uji-t menunjukkan bahwa persepsi ekowisata berpengaruh secara signifikan terhadap kepuasan wisatawan di Monkey Forest Ubud, Bali. Hasil ini mendukung Wang (2015) dalam jurnalnya yang berjudul "Visitor Perception, Interpretation Needs, and Satisfaction of EcoTourism: The Case of Taijiang National Park, Taiwan". Wang (2015) dalam jurnalnya tersebut menyatakan bahwa terdapat pengaruh 
yang signifikan antara persepsi ekowisata terhadap kepuasan wisatawan di Taman Nasional Taijiang, Taiwan.

Adanya rasa bangga mengkonsumsi produk ekowisata memberikan pemahaman bahwa wisatawan memiliki persepsi yang positif terhadap pelaksanaan praktek ekowisata. Sehingga ketika wisatawan berkunjung ke sebuah destinasi ekowisata, maka hal tersebut akan memberikan nilai kepuasan tersendiri bagi mereka. Fandeli (2002 dalam Arida, 2016: 22) menyatakan bahwa melalui ekowisata, wisatawan dan seluruh komponen yang terkait dengan penyelenggarakan wisata, diajak untuk lebih peka terhadap masalah lingkungan dan sosial, sehingga diharapkan sumber daya alam tetap lestari dan wisatawan mempunyai apresiasi lingkungan yang tinggi. Kepekaan wisatawan terhadap permasalahan sosial dan lingkungan membuat mereka lebih terfokus pada keinginan atas keterlibatan mereka untuk merealisasikan tujuan-tujuan mulia dalam pelaksanaan ekowisata. Sehingga dengan adanya persepsi positif terhadap ekowisata tersebut, maka kunjungan wisatawan ke sebuah destinasi ekowisata akan mampu memberikan pengalaman yang berkesan dan berujung pada terciptanya kepuasan mereka.

\section{SIMPULAN DAN SARAN Simpulan}

Secara garis besar, wisatawan yang berkunjung ke Monkey Forest Ubud memiliki pola pikir bahwa praktek ekowisata dilakukan sebagai realisasi dari upaya-upaya konservasi lingkungan, bentuk pelestarian budaya serta memberikan manfaat ekonomi secara langsung kepada masyarakat lokal. Sedangkan pada sisi tingkat kepuasan, wisatawan secara keseluruhan merasa puas terhadap daya tarik wisata Monkey Forest Ubud. Di sisi lain, berdasarkan hasil pengujian hipotesis melalui uji signifikansi (uji t) menunjukkan bahwa persepsi ekowisata berpengaruh secara signifikan terhadap kepuasan wisatawan di Monkey Forest Ubud, Bali.

\section{Saran}

Pihak Monkey Forest Ubud sebaiknya melibatkan wisatawan secara langsung dalam praktek implementasi konsep ekowisata. Salah satu caranya dapat dilakukan dengan mengajak wisatawan dalam kegiatan-kegiatan konservasi lingkungan misalnya diadakan kegiatan rutin tanam seribu pohon setiap tahun dan mengajak wisatawan untuk berpartisipasi pada kegiatan rutin tersebut. Hal ini dilandasi oleh hasil yang mengemukakan bahwa persepsi ekowisata berpengaruh secara signifikan terhadap kepuasan wisatawan di Monkey Forest Ubud, Bali. Sehingga dengan melibatkan wisatawan secara langsung dalam praktek pelaksanaan ekowisatanya, diharapkan mampu meningkatkan kepuasan wisatawan dalam kunjungannya ke Monkey Forest Ubud.

Selain itu, Pihak Monkey Forest Ubud disarankan untuk meningkatkan faktor-faktor pada indikator-indikator kepuasan wisatawan yang menjadi prioritas utama seperti kebersihan toilet, penempatan beberapa tempat sampah, kebersihan seluruh area (termasuk area parkir) serta kecakapan staf dalam memberikan informasi guna menjawab permintaan pengunjung. 


\section{DAFTAR PUSTAKA}

Arida, N.S. 2016. Dinamika Ekowisata Tri Ning Tri di Bali. Denpasar: Pustaka Larasan.

Damanik, Janianton dan Helmut F. Weber. 2006. Perencanaan Ekowisata: dari Teori ke Aplikasi. Yogyakarta: Penerbit Andi.

Irawan, Handi. 2008. Membedah strategi kepuasan pelanggan. Jakarta: PT Gramedia.

Sudiarta, I Nyoman dan Suardana, I Wayan. 2016. Tourism Destination Planning Strategy: Analysis and Implementation of Marketing City Tour in Bali. Procedia - Social and Behavioral Sciences, 227, page: 664-670.

Sugiyono. 2014. Metode Penelitian Kuantitatif Kualitatif dan $R \& D$. Bandung: Alfabeta.

Sullivan, Kate, dkk. 1995. Environmental Guidelines for Coastal Tourism Development in Sri Lanka. Website: http://pdf.usaid.gov/pdf_docs/PNABZ4 62.pdf (Diakses Pada 7 Oktober 2016).

The World Tourism Organization (UNWTO). 1998. Guide for Local Authorities on Developing Sustainable Tourism. Madrid: Author.

The World Tourism Organization (UNWTO). 1999. International Tourism: a Global Perspective. Madrid: Author .

Wang, Wei-Ching. 2015. Visitor Perception, Interpretation Needs, and Satisfaction of Eco-Tourism: The Case of Taijiang National Park, Taiwan. Vol 5 No 2 (2015), pp. 180-200 Website: http://rabida.uhu.es/ (Diakses Pada 10 Oktober 2016).

www.tripadvisor.co.id (Diakses Pada 23 Oktober 2016) 